\title{
MICROBIOLOGICAL BIOREMEDIATION OF THE KAMIENNA GÓRA DAM RESERVOIR
}

\author{
Robert Mazur ${ }^{1 \bowtie}$, Marcin Sitarek² \\ ${ }^{1}$ Department of Geoinformation Photogrammetry and Remote Sensing of Environment Faculty of Mining Surveying and Environ- \\ mental Engineering, AGH University of Science and Technology, al. Mickiewicza 30, 30-059 Krakow \\ ${ }^{2}$ ACS Poland Sp. z o. o, Aqua Clean Service
}

\begin{abstract}
Aim of the study

Study of the effects of the microbiological bioremediation process carried out as a part of a purification process of a reservoir in Kamienna Góra.

Material and methods

A number of field measurements were made, i.e. thickness of bottom sediments, light transmission, and physicochemical analyses of waters. Activities undertaken in the bioremediation process were described. The final effects have been characterised.

\section{Results and conclusions}

The microbiological bioremediation process has contributed to the reduction of bottom sediments (organic fractions) by $30-100 \%$ at the selected measuring points. There was an improvement in the euphotic zone conditions from $70-100 \%$ in the examined points. The level of organic pollutants in water has also partially improved. The concentrations of the studied nutrients did not decrease, and even in some points they increased in 2018. Despite visible changes in the water quality in the reservoir, and almost complete elimination of organic fractions in bottom sediments, an increase in nutrients in the flood waters could be expected. In the last year of research, complete elimination of algal blooms was noted and ecotones were located in places of their earlier occurrence. The reservoir is still exposed to pressure from pollutants brought in by waters of the Zadrna River. If sources of pollution are not eliminated, this type of treatment will have to be repeated in subsequent seasons to maintain the quality of the reservoir water.
\end{abstract}

Keywords: eutrophic lake bioremediation, microbiological bio-preparation, polluted lakes, water degradation, water reclamation.

\section{INTRODUCTION}

The dam reservoir in Kamienna Góra was put into exploitation in 1972, and it performs several utility functions in the region of its location. The reservoir is supplied with water of the Zadrna River whose quality from the beginning of its operation remains outside the water quality classes. High concentrations of or- ganic pollutants and nutrients come from a variety of sources, ranging from improperly treated wastewater to surface runoff from agricultural or industrial areas (Chmielowski and Ślizowski, 2008; Kuriqi, 2014; Kuriqi et al., 2016; Mazur et al., 2016; Kaczor et al., 2017). The lake is located in an urban agglomeration, and the adjacent areas do not belong to an agricultural area. The construction of the reservoir and the location

凶e-mail: mazurrob@gmail.com 
of its inflow and outflow, as well as the dyke separating the reservoir, make it possible to distinguish two types of aquatic environments: flowing water (with the prolonged flow) and stagnant one (see: Fig. 1). The poorest water exchange and the most massive accumulation of organic matter occur on both sides of the dyke (points $\mathrm{P} 1, \mathrm{P} 5$ and $\mathrm{P} 3$, and $\mathrm{P} 4)$. This situation is worsened by winds causing waves and an additional influx of pollutants from the rest of the lake (without the possibility of low tide). Due to the shallow depth of the lagoon, it is characterised by abundant water mixing throughout the year (see: Table 1).

A very long time of water retention harms the quality of water due to long-term persistence of pollutants that flow into the lake with the Zadrna's water. Recreational activities on the lake and swimming were prohibited due to sanitary threats. The lack of a proper management plan for the reservoir infrastructure prevented the correct flow of water through the
Table 1. Morphometric characteristics and mycotic type of the reservoir

\begin{tabular}{cccccc}
\hline No. $\begin{array}{c}\text { Name of water } \\
\text { reservoir }\end{array}$ & $\begin{array}{c}\text { Surface } \\
\text { area } \\
{[\text { ha] }}\end{array}$ & $\begin{array}{c}\text { Volume } \\
{\left[\mathrm{hm}^{3}\right]}\end{array}$ & $\begin{array}{c}\text { Depth [m] } \\
\text { (avg. }-\end{array}$ & $\begin{array}{c}\text { Lake } \\
\text { max })\end{array}$ & types \\
\hline $1 \quad \begin{array}{c}\text { Kamienna Góra } \\
\text { Dam Reservoir }\end{array}$ & 7,34 & 0,120 & $1.5-2,6$ & polimictic \\
\hline
\end{tabular}

weir until recently. Efforts of the local administration, and modernisation works improved the functioning of hydrotechnical infrastructure (http://www.kamiennagora.pl/). Decay processes of bottom sediments were the cause of significant odour nuisance in the area of the lake shoreline. In 2016, the lake was restocked with fish juveniles at the fingerling stage with a total weight of $1,600 \mathrm{~kg}$. Species are kept mainly in the waters of the lagoon, i.e. carp (Cyprinus carpio L.)

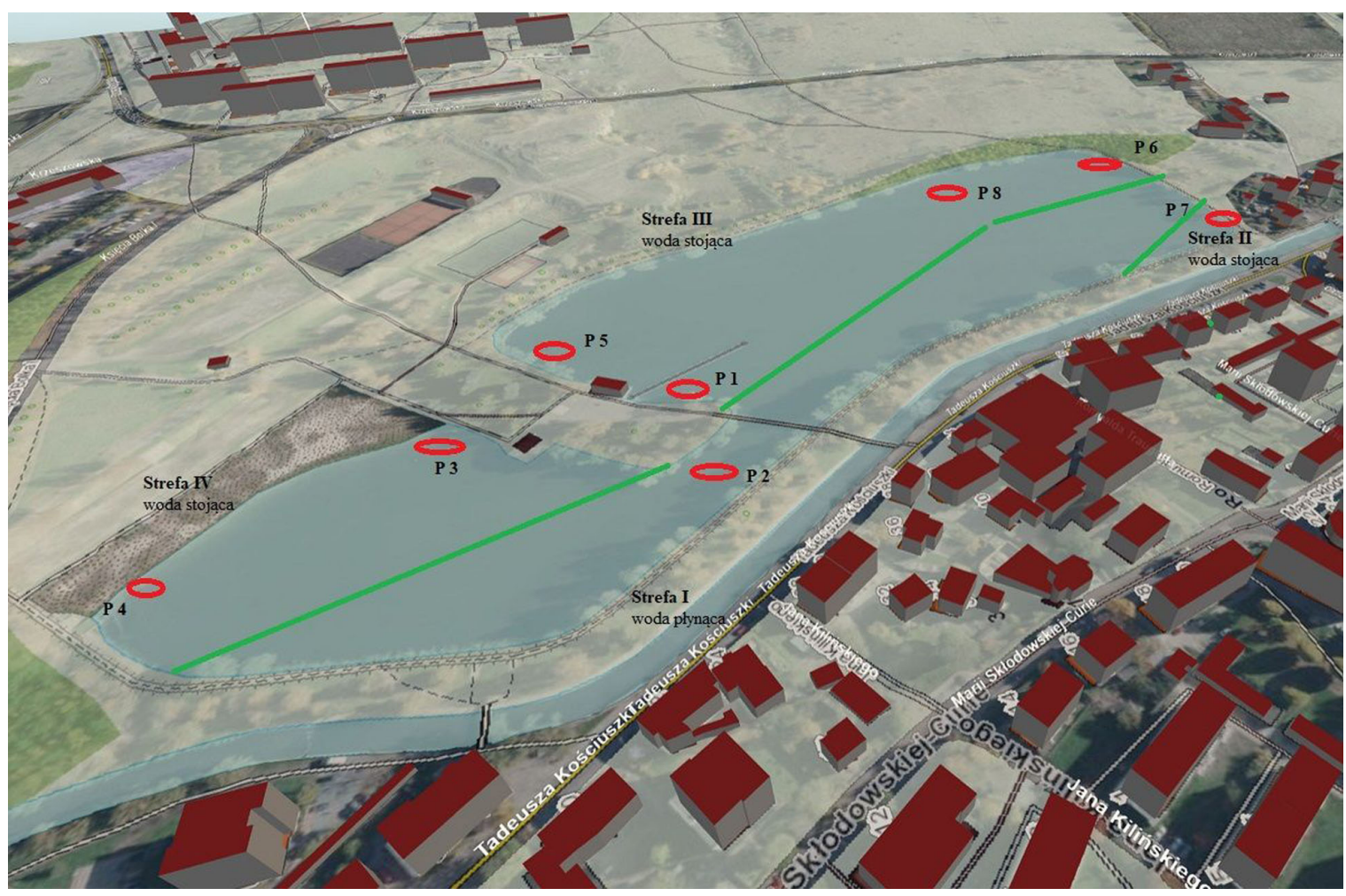

Fig. 1. Division of the reservoir into zones and determination of measuring points. The boundaries of individual zones are marked with green lines. Measuring points are marked in the form ellipses and numbered from P1 to P7. Map - 3D model of the Kamienna Góra Reservoir. Source: www.geoprotal.gov.pl 
(most numerous population), tench (Tinca tinca L.), roach (Rutilus rutilus L.), ide (Euciscus idus L.), silver Prussian carp (Carassius gibelio Bloch.), perch (Perca fluviatilis L), grass carp (Ctenopharyngodon idella L.) and bream (Abramis brama L.). Few pike individuals (Esox lucius L.) were also let into the water of the lake. Fishing preferences dictate the above species diversity of ichthyofauna in the fishery area. Lake biomanipulation methods, such as "up to down", used to mitigate the intensity of "algae bloom" (Berg et al., 1997; Horppila et al., 1998; Søndergaard et al., 2000; Czerniawski et al., 2015; Lemmens et al., 2018) do not apply. Until 2018, eutrophication processes were very intense here and negatively affected the development of ichthyofauna and other organisms into aquatic ecosystems (see: Fig. 2).

In 2017 , before the start of bioremediation, algal blooms were still the biggest issue (both, in the form of intense green foam and of increased water turbidity), and the water was brownish. The level of silting of the lake also increased, and the predominance of organic fractions characterised stagnant sediments. The above processes threatened with a permanent degradation of the aquatic environment and caused nuisances to people staying in its surroundings. Following the requirements of the WFD, local authorities were obliged to carry out activities to improve the condition of the reservoir. In 2017, a microbiological bioremediation process focused on the process of bottom sediment mineralisation and reduction of their layer was carried out

The choice of method was based on financial criteria and a on guarantee of the effectiveness of the bioremediation process due to the use of biotechnology-based on bio-preparations of effective microorganisms. Competitive methods of mechanical desludging or regulation are characterised by costs many times higher compared to bioremediation and are invasive for the aquatic environment.

In 2017, the first stage of microbiological bioremediation began. Biopreparations were being introduced once during the growing season in a given year. To perform bioremediation, the reservoir was divided into zones taking into account its morphological features and its environmental conditions. Zone I - flowing water and Zone II, III and IV as stagnant water (see: Fig. 1). In each bioremediation procedure, 10.000 li-

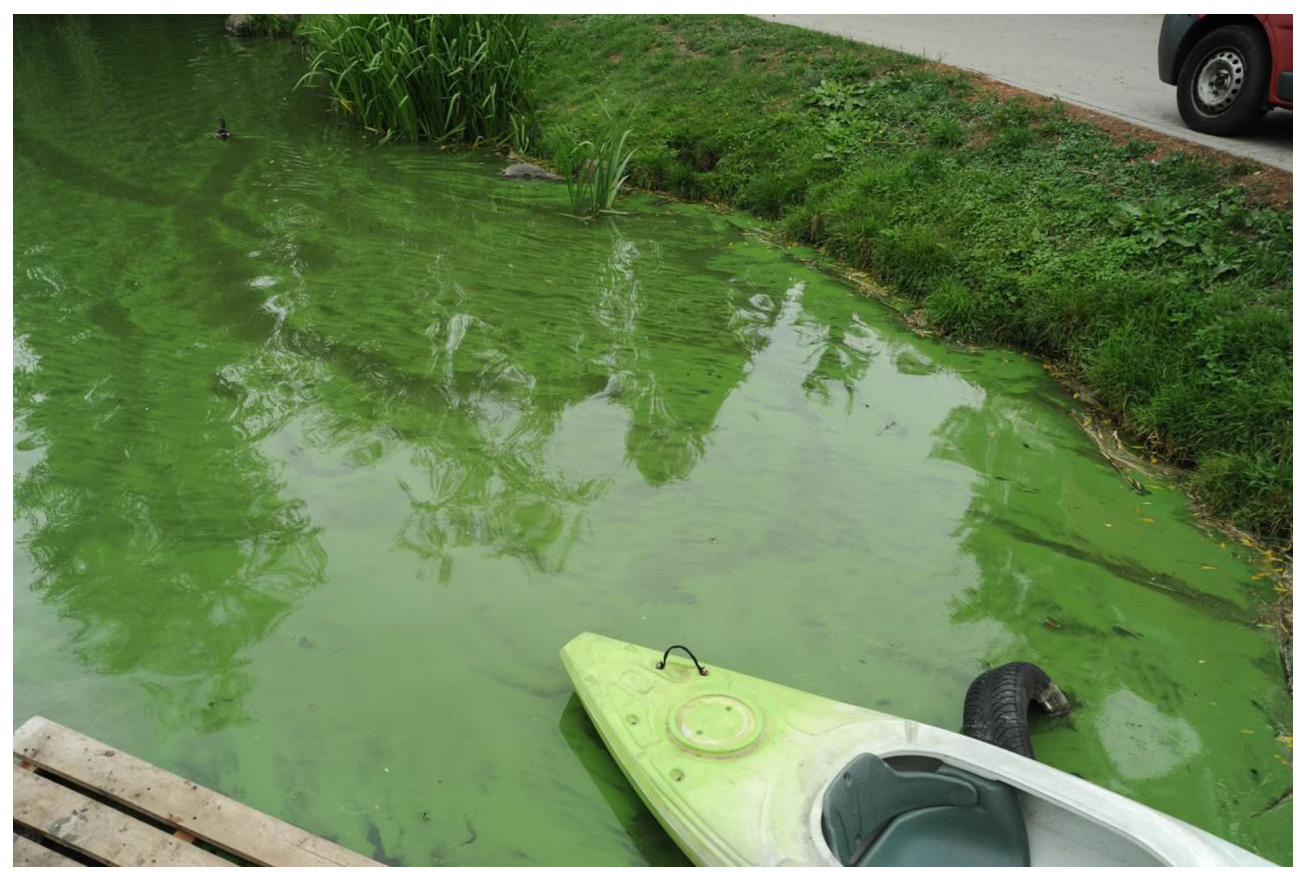

Fig. 2. Intensive eutrophication process of the reservoir water in Kamienna Góra (May 2018), before microbiological bioremediation (June 2018) 
tres of directional microbiological preparations, suited to the lake conditions, were used. Four preparations manufactured by ACS Poland were used in the process: ACS AQUA_1, ACS AQUA_2 CW, ACS AQUA_6A 1 and ACS AQUA_7 Sediment. A characteristic feature of these products is that they contain only living and active microorganisms. When applying microorganisms, water was also aerated throughout the entire water area. The preparations were introduced in zones at various depths: in the surface layer, in the benthos zone, and into the sediment.

In addition, hydrophyte ecotones were introduced in 2019 to restore the degraded littoral zone by planting macrophytes in the reservoir's edge zone. They act as a hydrophyte pre-treatment system - they support the treatment processes initiated and targeted by microorganisms (ecotones No. 2-8) and constitute a physical barrier preventing the influx of pollutants (ecotone No. 1, located at the inflow of the reservoir). As part of these treatments, plants were planted in appropriately designated areas of the lake. Macrophytes from the group of helophytes were used, i.e. reed (Phragramites
Australis), broadleaf cattail (Typha latifolia), lesser bulrush (Typha angustifolia, L.), sweet flag (Acorus calamus), great manna grass (Glyceria aquatica) and greater pond sedge (Carex riparia), which buffer the negative impact of pollutants from diffuse sources and capture nutrients from water. The location of the ecotones is shown in Fig. 3. The first ecotone is located in the inflow to the reservoir, in the zone of the highest emission of pollutants. The second group is ecotones No. 2, 3, 4, 5, and the next ecotones are No. 6, 7, 8 (see: Fig. 3).

In order to assess the effectiveness of bioremediation treatments, the author conducted an assessment of the water quality of the reservoir and bottom sediments.

\section{METHODOLOGY}

Measurement of the thickness of bottom sediments:

1. The measurement of the thickness of the soft, upper fraction of bottom sediments (with a significant share of organic matter) was made using the author's method using an endoscopic came-

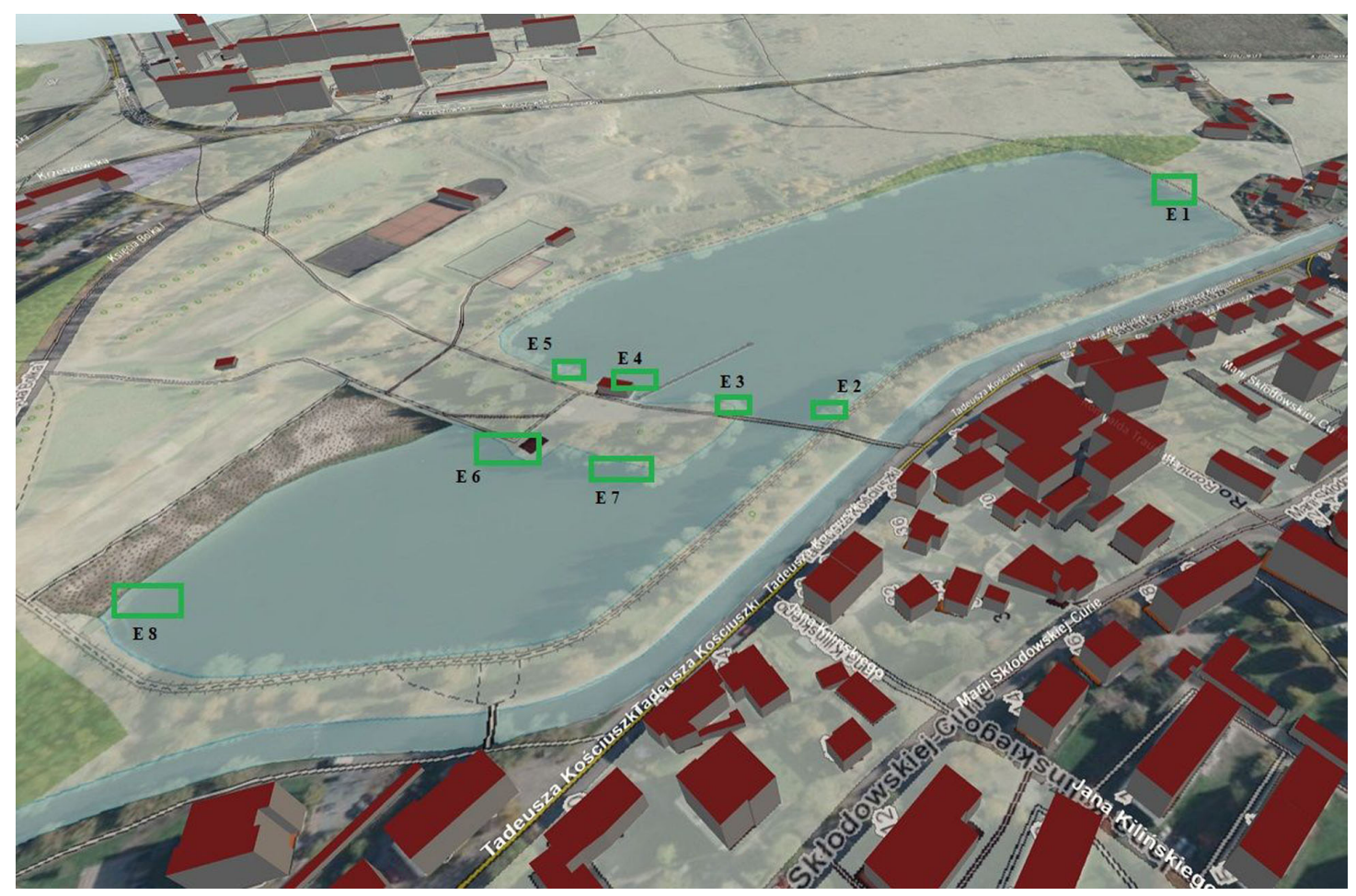

Fig. 3. The location of ecotones from helophytes - consistent with the natural habitats of the species. Source: www.geoportal.gov.pl 
ra. The installation consists of an arm lowered to a certain depth, equipped with a light source, a recording camera and a sludge thickness meter, scaled to an accuracy of $1 \mathrm{~cm}$.

2. The image from the bottom examination is displayed on the computer monitor in online mode. In natural water bodies, the measurement is made in the coastal zone of the lake and in the so-called euphotic zone (up to a depth of $1.8 \mathrm{~m}$ ). Water transparency was measured with the Secchi disk method.

\section{Laboratory analyses of selected water quality parameters Table 2}

The appropriate bioremediation effect affects both the reduction of anthropogenic eutrophication as well as the biodegradation of organic fractions in bottom sediments.

The sampling process took place once a day during the week in the same months of the growing season. The results are average values from the measurements and are completely sufficient to compare the state of the water reservoir before and after the bioremediation process.

\section{RESULTS}

The assessment was made in 12-month periods after the microbiological bioremediation procedures performed.
The process of mineralisation of the organic fraction of bottom sediments and change of water transparency:

The effects of the different stages of biodegradation were evaluated at intervals of twelve months. All measurements were made in June in a given year. The results in Figure 4 indicate that the highest decrease in silting level was observed in 2018. During this period, a significant improvement in light transmission in the water column was also observed (see: Fig. 5). The organic fractions of pollution in bottom sediments as well as in water are a source of organic carbon (a food source) for the microbial consortia (originated from the applied biopreparations). In the bioremediation process, we observe a high level of organic biodegradation, as well as a reduction of pollution in water and mineralisation of bottom sediments.

\section{Physical and chemical parameters}

The concentrations of organic pollutants and suspended solids in water show a downward trend (see: Figs. 6 and 7), but these are not as significant differences as in the case of transparency and sludge reduction. A comparable rate of biodegradation of both easily and hardly degradable organic fractions

Table 2. Physical and chemical analyses of selected water quality parameters - a list of methods used

\begin{tabular}{|c|c|c|c|c|}
\hline Indication & Unit & Research Method & $\begin{array}{l}\text { The limit of } \\
\text { quantification }\end{array}$ & $\begin{array}{c}\text { Uncertainty expressed } \\
\text { as precision }\end{array}$ \\
\hline Basicity & $\mathrm{mmol} \cdot \mathrm{dm}^{-3}$ & PN-EN-ISO 9963-1: 2003 & & \\
\hline Permanganate index & $\mathrm{mgO}_{2} \cdot \mathrm{dm}^{-3}$ & PN-EN-ISO 8467: 2001 & $\pm 0,6$ & $1,2 \%$ \\
\hline $\mathrm{BOD}_{5}$ & $\mathrm{mgO}_{2} \cdot \mathrm{dm}^{-3}$ & $\begin{array}{l}\text { PN-EN-18899-1: } 2002 \\
\text { PN-EN-18899-2: } 2002\end{array}$ & $\pm 4,5$ & $11 \%$ \\
\hline $\mathrm{COD}-\mathrm{Cr}$ & $\mathrm{mgO}_{2} \cdot \mathrm{dm}^{-3}$ & ISO 15705 & & \\
\hline Ammonium Nitrogen & $\mathrm{mgNH}_{4} \cdot \mathrm{dm}^{-3}$ & ISO 7150 & $\pm 0,08$ & $1,7 \%$ \\
\hline Nitrite Nitrogen & $\mathrm{mgNO}_{2} \cdot \mathrm{dm}^{-3}$ & EN 26777 & $\pm 0,02$ & $1,5 \%$ \\
\hline Nitrate Nitrogen & $\mathrm{mgNO}_{3} \cdot \mathrm{dm}^{-3}$ & ISO 7890-1 & $\pm 0,5$ & $1,5 \%$ \\
\hline Total nitrogen & $\mathrm{mgN} \cdot \mathrm{dm}^{-3}$ & $\begin{array}{c}\text { EN-ISO } 11905 / 1 \\
\text { ISO 7890-1 }\end{array}$ & $\pm 0,5$ & $1,3 \%$ \\
\hline Total phosphorus & $\mathrm{mgP} \cdot \mathrm{dm}^{-3}$ & EN-ISO 6878 & $\pm 0,5$ & $1,2 \%$ \\
\hline Total suspension & $\mathrm{mg} \cdot \mathrm{dm}^{-3}$ & PN-EN 82: 2005 & & $2 \%$ \\
\hline
\end{tabular}




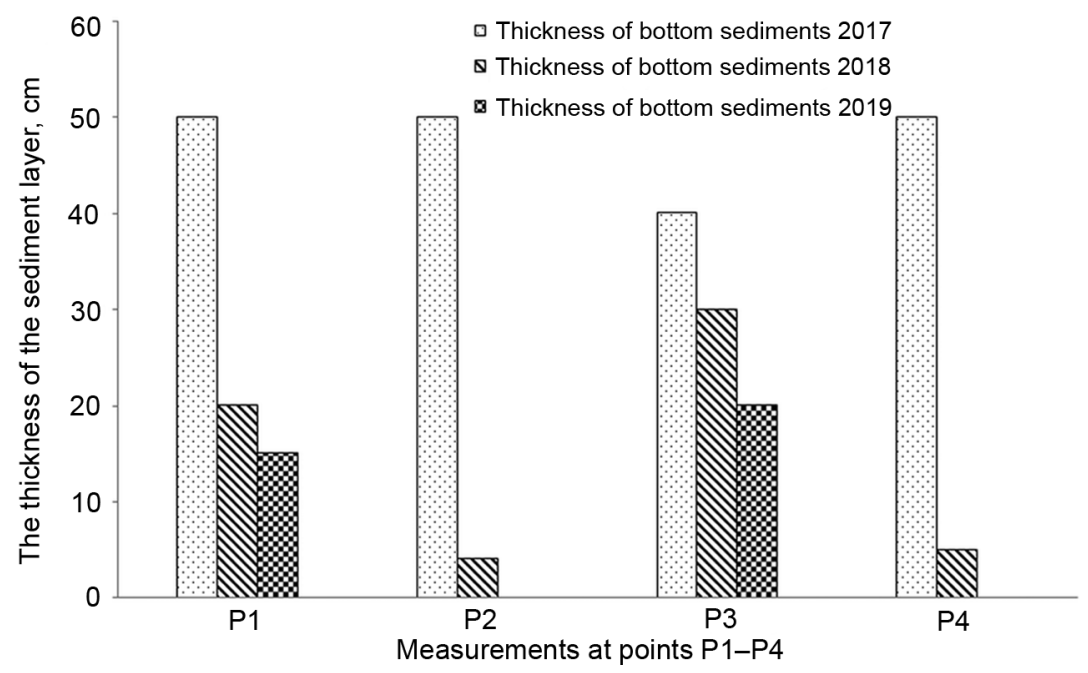

Fig. 4. Changes in the thickness of bottom sediments in 2017-2019 at points P1-P4, measurements in June

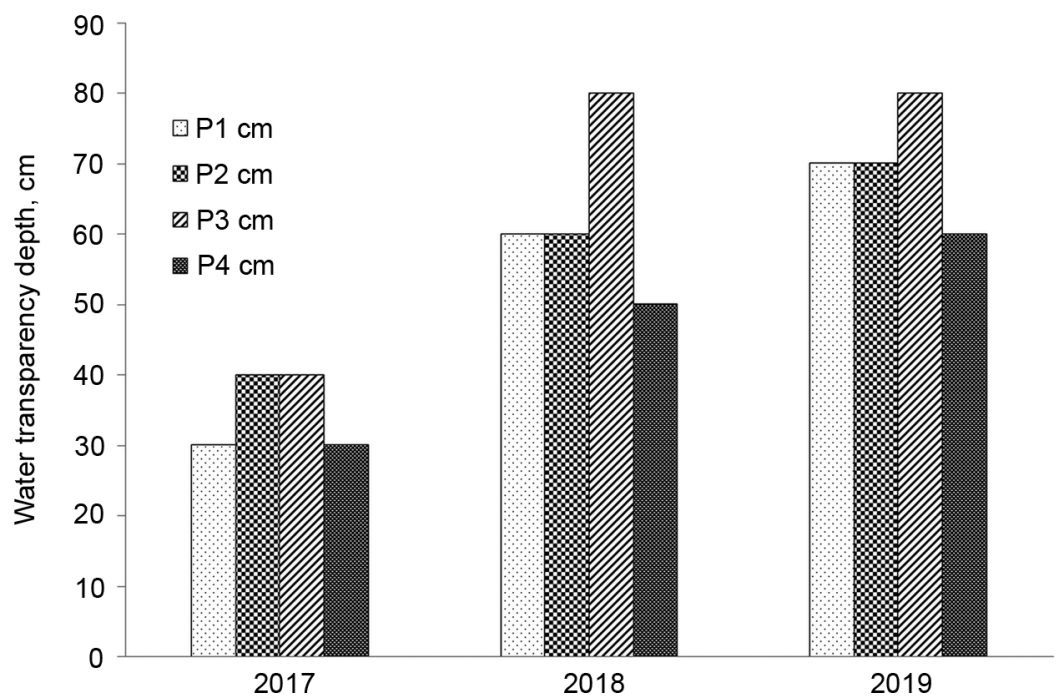

Fig. 5. Changes in water transparency in 2017-2019 (in June), measured with a Secchi disk

was observed in the reservoir, as a result of the high concentration of introduced consortia of the effective microorganisms.

\section{Changes in nutrients concentration}

Changes in the concentration of nutrients compounds during the monitoring period of the effects of bioremediation do not show variable trends. In many cases, we observe their increase and slight decreases, which are not significantly different from the period before the process (see: Fig. 8-9). These types of changes result from the intensive processes of mineralisation of organic fractions in bottom sediments, as a result of which a significant amount of nutrients was released into the water. 

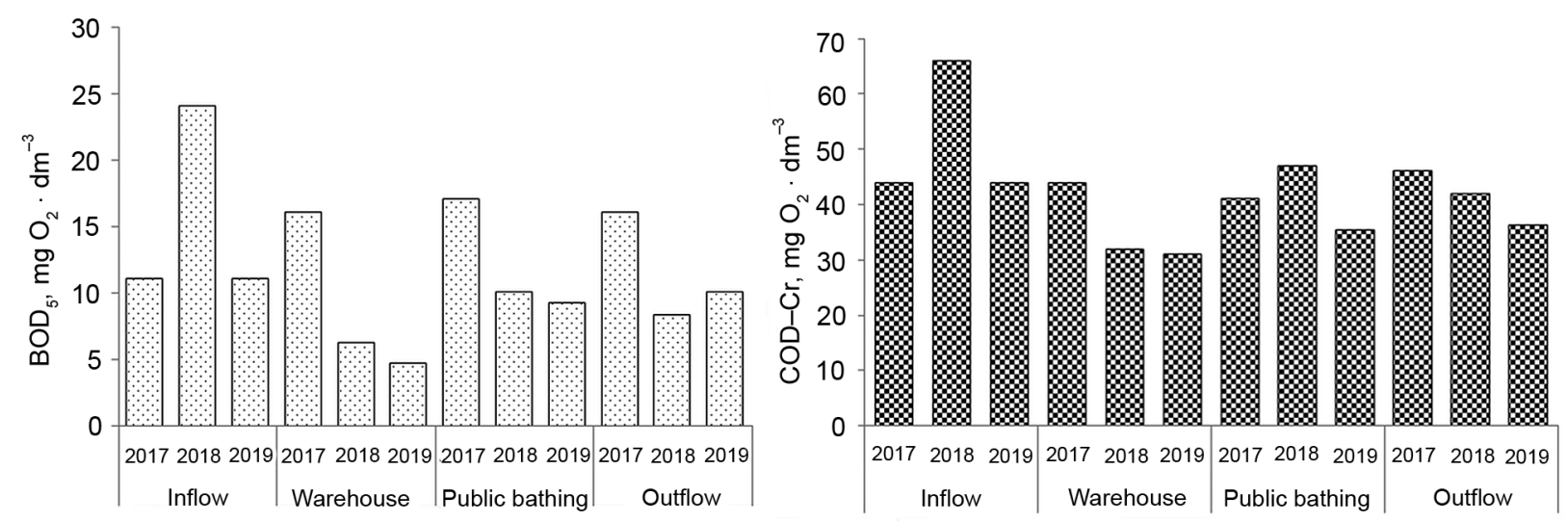

Fig. 6. Changes in BOD5 and COD values in June 2017-2019

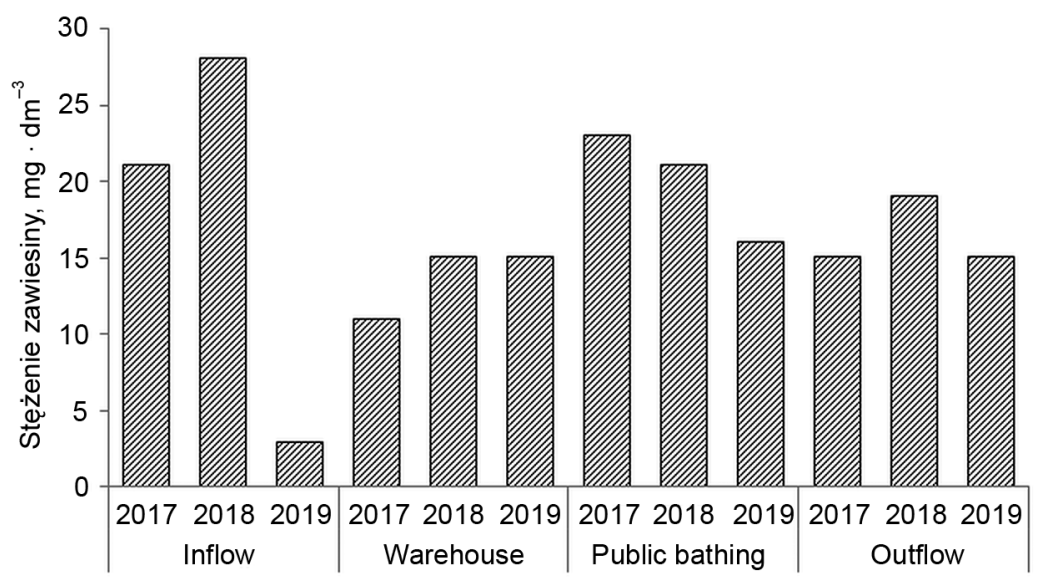

Fig. 7. Changes in suspension concentration over the sampling period (June) in 2017-2019

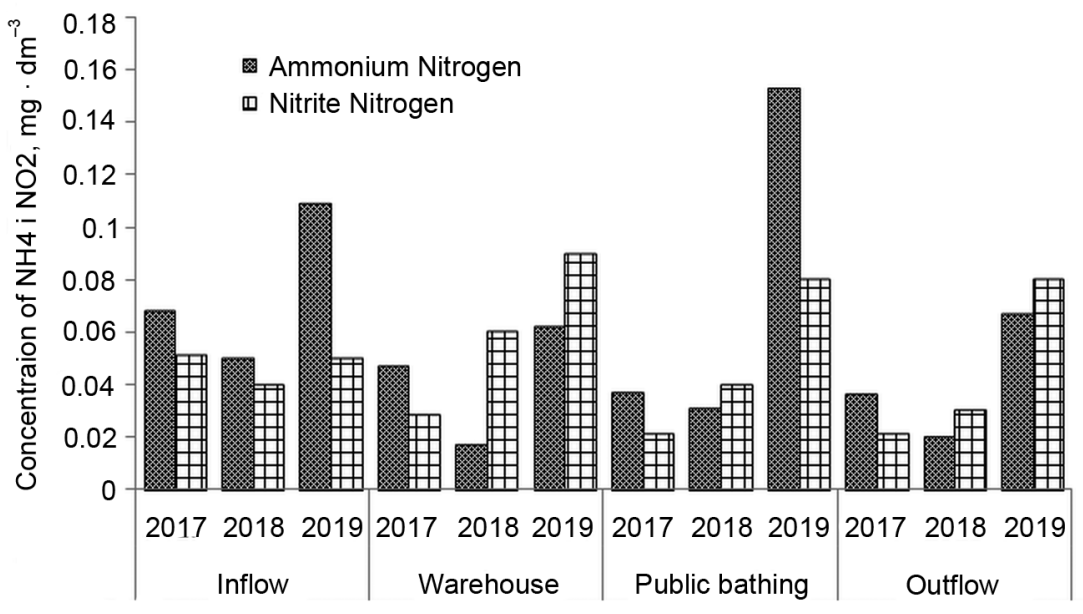

Fig. 8. Changes in the concentration of ammonium and nitrate ions in June (in 2017 and 2019) 


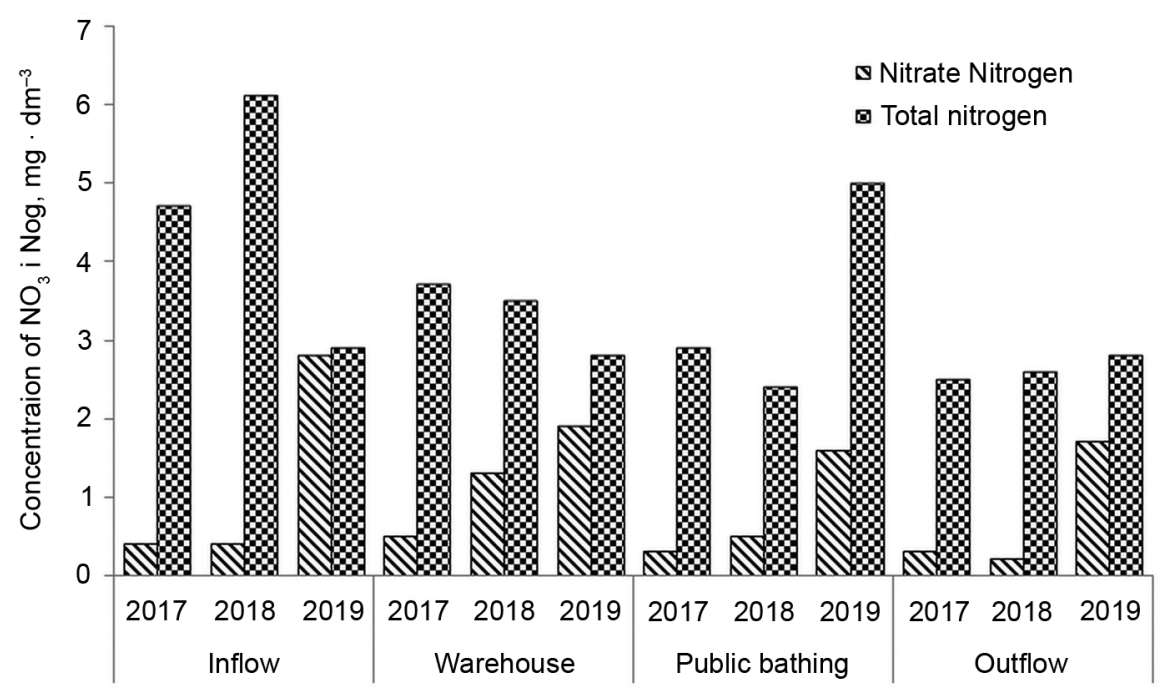

Fig. 9. Changes in the concentration of nitrate ions and total nitrogen in June (in 2017 and 2019)

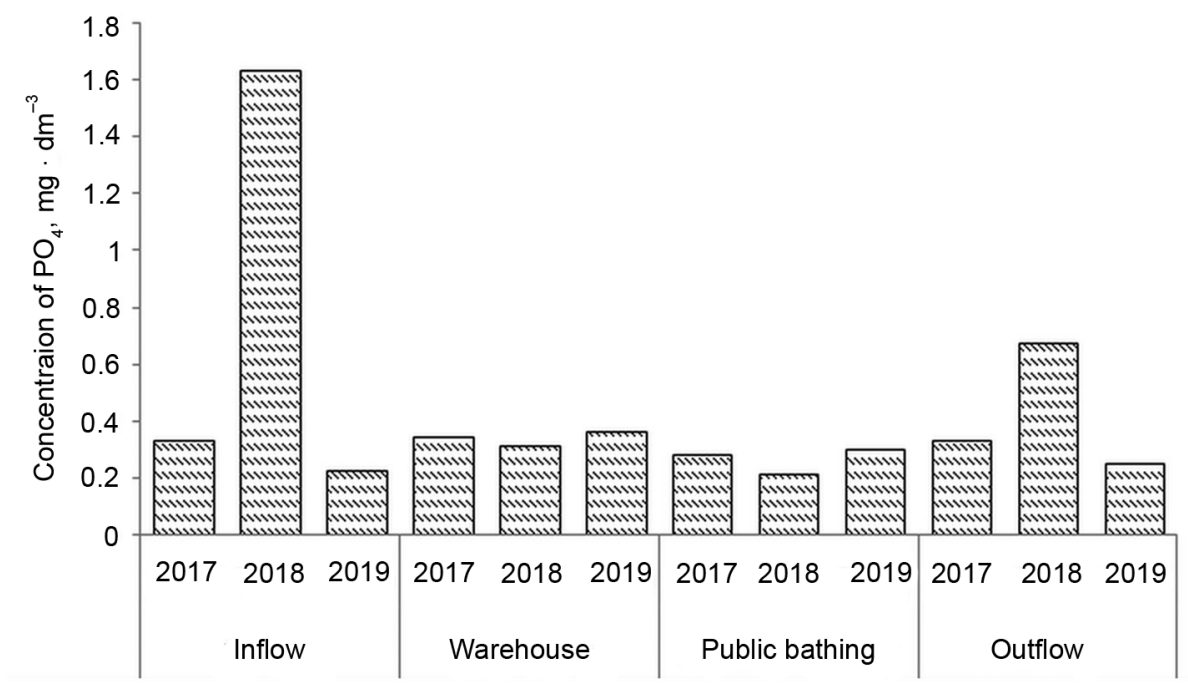

Fig. 10. Changes in the concentration of ortho-phosphate ions in June (in 2017 and 2019)

\section{DISCUSSION}

Several physical, chemical and biological methods are used in the industry practice of lake reclamation (Singh, 1982; Howard-Williams et al., 2018). Mixed technologies are most often used depending on the level of water pollution and the size of a reservoir (Gibson, 2000;
Premazzi et al., 2005; McDowell et al., 2018). The most crucial goal of each method is to achieve improvements in selected water quality parameters (Søndergaard and Jeppesen, 2007; Hupfer et al., 2016). Unfortunately, few companies pay attention to maintaining the durability of the effect after the reclamation process (Søndergaard et al., 2007; Hupfer et al., 2016). 
In many cases, it is not possible to achieve a longterm purification effect, due to the lack of elimination of sources of pollution discharge to the lake (Søndergaard and Jeppesen, 2007). The dam reservoir in Kamienna Góra is still exposed to pressure from the continuous influx of organic pollutants and nutrients inflowing with Zadrna's water. If the diffuse and area sources of pollution in the Zadrna catchment are not eliminated, bioremediation will have to be repeated in order to maintain the obtained quality of the reservoir water. The microbiological bioremediation process has visibly improved the water status by reducing the intensity of alga blooms (see: Fig. 11), reduction of the bottom sediment layer (organic fraction) (see: Fig. 4), and complete elimination of putrefactive odours from bottom sediments. The scientific literature describes many examples of successes in the process of revitalisation of water reservoirs (Annadotter et al., 1999; Søndergaard et al., 2007; Jeppesen et al., 2007), however, the majority of the final effect was obtained after many seasons of the purification process (Søndergaard et al., 2008; Gulati et al., 2008). Maintaining the long-term effects of improving the ecological status of water requires, however, the elimination of sources of pollution (Dunalska and Wiśniewski, 2016), therefore, despite the temporary effects of improvement, the reservoirs undergo secondary degradation in subsequent seasons (Suding, 2011). The conditions of the euphotic zone have significantly improved, light transmission has increased by $100 \%$ at selected points (see: Fig. 5). In zones of the bays with stagnant water, intense blooms were nevertheless noted in 2018. They were caused by an increased supply of nutrients released during the biodegradation process of organic fractions from bottom sediments (see: Fig. 8-10). Apart from the places of water stagnation, no further blooms were found in the reservoir and the light transmission was significantly better than before the reclamation. The second treatment of targeted biopreparations in 2018 reduced blooms in all areas of the lake. In places where the intensity of algal blooms increased from 2018, the location for macrophytes forming the ecotone zones was selected. In 2019, an increased growth of reed bed and an improvement in species biodiversity of the coastal zone were observed. In lakes with high levels of organic sediments, during the mineralisa- tion process substances from the group of sorbents that bind nitrogen and phosphorus can be additionally used. In many cases, chemical sorbents based on PIX or PAX compounds and their derivatives are used (Gibbs and Hickey, 2018). Despite the widespread use of this type of substance, their safe impact on tanks cannot be guaranteed in the long term of their use (Bonisławska et al., 2012). Kaolin clays, a fragmented fraction of silica-calcium rocks (Pol. opoka), are much safer for aquatic ecosystems (Bus and Kaczmarczyk, 2014), and various forms of zeolites (Gibbs \& Özkundakci, 2011; Wasik et al., 2017). The performed microbiological bioremediation procedures can be included in the cheapest methods of polluted water reclamation in both, natural and artificial reservoirs. Methods using biopreparations are not invasive compared to many mechanical desludging techniques (Cook, 1980). There were no disorders in the trophic network resulting from the impact of the used preparations. The improvement of water quality undoubtedly positively affects the reconstruction of the trophic structure appropriate for a given aquatic ecosystem (Hamilton and Landman, 2011). The consortia of bacteria and microorganisms selected for the treatment process also stimulate autochthonous aerobic bacteria, which carry out an intensive process of biological decomposition of organic pollutants in reservoir waters. Along with the application of biopreparations, additional zonal aeration treatments are carried out that activate the processes of aerobic biodegradation. Similar operations are carried out in heavily contaminated soils, where after introducing directional preparations, the process of soil structure ventilation is provided (Kaszycki et al., 2002). The applied methods belong to tools from the group of environmental biotechnologies, whose intensive development has been observed in the last decade, and belong to the group of best available practice (Zhang et al., 2007) in Environmental Engineering and active protection of freshwater resources (Makarewicz and Bertram, 1991). Maintaining pressure from pollution to water is the main limitation for all methods of water reservoir remediation (Imboden, 1992; Huang et al., 2007). Many authors have shown that methods of biological treatment of degraded lakes are most appropriate in most cases (Moss, 1990; Cook et al., 2013; Cook et al., 2016). The introduction of eco- 
A.

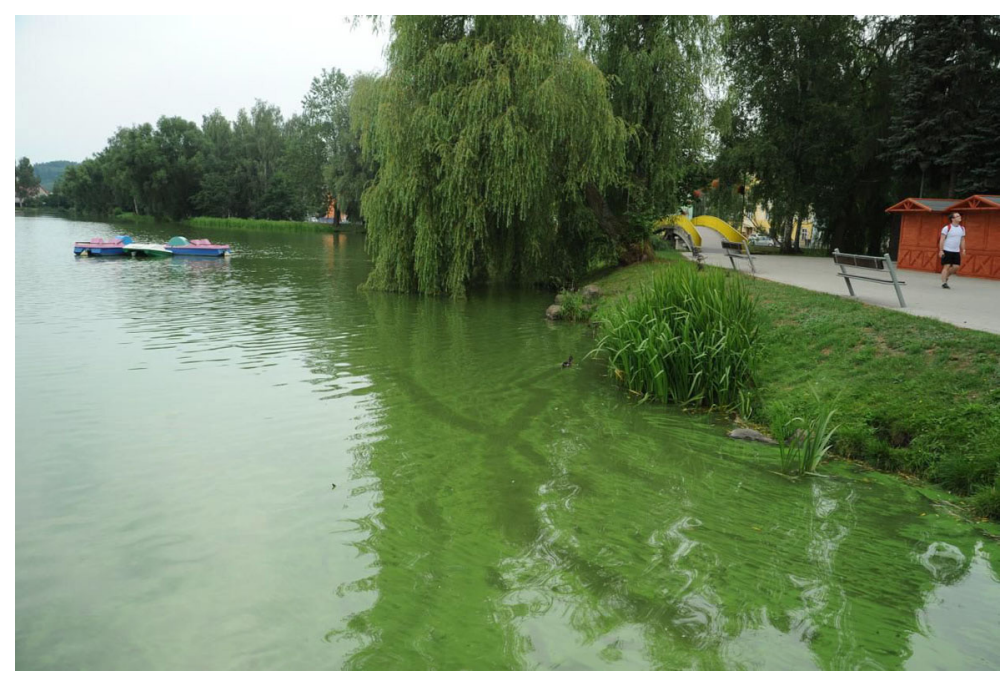

B.

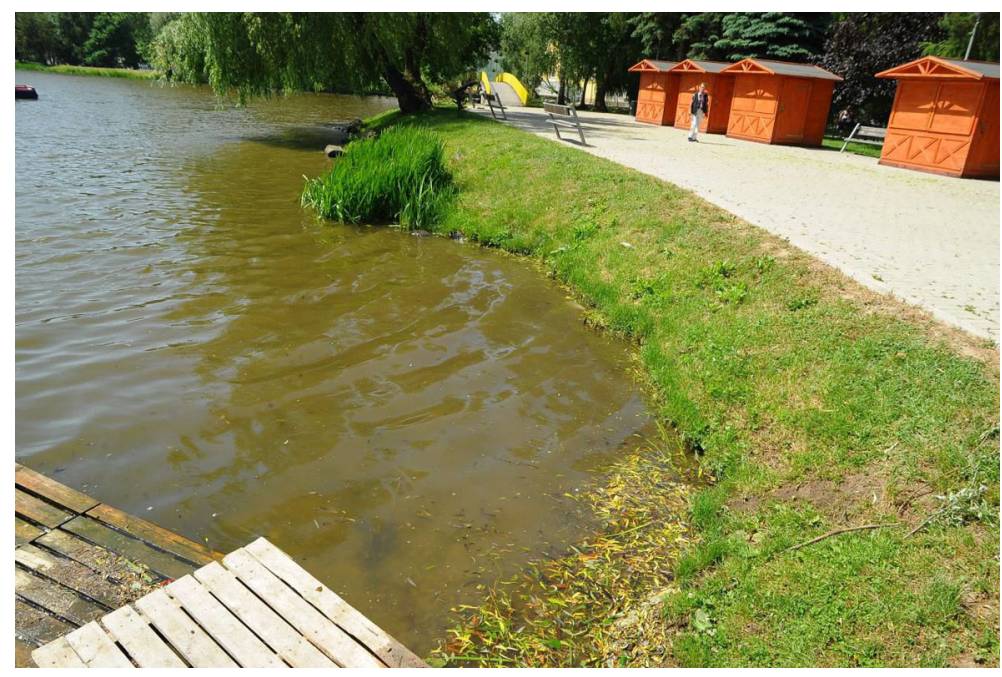

Fig. 11. Changes in the intensity of algal blooms A. 2018 and B. 2019

tones in the structure of the reclaimed water of the reservoir have a positive effect on the ecological status of the freshwater environment (Chen et al., 2019). A general increase in species biodiversity of the littoral zone plants was also visible in 2019.

\section{CONCLUSIONS}

The process of assessing the effectiveness of microbiological bioremediation has shown the desirability of its application to this type of small water reservoirs.

1. The microbiological bioremediation process has brought the intended effects resulting in the im- provement of selected quality parameters of the water in the reservoir in Kamienna Góra.

2. After the second stage of application of bio-preparations in 2018, in the next growing season a general improvement in water transparency and deeper penetration of light rays was observed.

3. The effects of sediment mineralisation and the disappearance of odour nuisance in lake zones were already observed in the first stage of the bioremediation process.

4. A general increase in species biodiversity of the littoral zone plants was also visible in 2019. 
5. Plantings of macrophytes forming ecotone zones were carried out in areas with a high risk of "algal blooms" resulting from the specificity of the conditions of the aquatic environment characterised by stagnant water.

Microbiological bioremediation supported by adsorbents to reduce nutrients in the process of their increased supply may become the dominant technology in the small water reservoirs reclamation and bathing areas reclamation.

This paper was prepared within the scope of the research subsidy of the Ministry of Science and Higher Education for AGH UST, no. 16.16.150.545

\section{REFERENCES}

Annadotter, H., Cronberg, G., Aagren, R., Lundstedt, B., Nilsson, P. Á., Ströbeck, S. (1999). Multiple techniques for lake restoration. In The Ecological Bases for Lake and Reservoir Management, 77-85. Dordrecht: Springer.

Berg, S., Jeppesen, E., \& Søndergaard, M. (1997). Pike (Esox lucius L.) stocking as a biomanipulation tool Effects on the fish population in Lake Lyng, Denmark. In Shallow Lakes' 95, 311-318. Dordrecht: Springer.

Bonisławska, M., Tański, A., Nędzarek, A., Tórz, A. (2012). Effect of the Coagulants PAX and PIX on the Embryonic Development of Pike (Esox lucius L.). Limnological Review, 12(3), 125-132.

Bus, A., Karczmarczyk, A. (2014). Charakterystyka skały wapienno-krzemionkowej opoki w aspekcie jej wykorzystania jako materiału reaktywnego do usuwania fosforu z wód i ścieków. Infrastruktura i Ekologia Terenów Wiejskich, (II/1).

Chen, F., Lu, S., Hu, X., He, Q., Feng, C., Xu, Q., \& Guo, H. (2019). Multi-dimensional habitat vegetation restoration mode for lake riparian zone, Taihu, China. Ecological Engineering, 134, 56-64.

Chmielowski K., Ślizowski R. (2008). Wpływ frakcji uziarnienia filtrów piaskowych o przepływie pionowym na stężenie wybranych zanieczyszczeń w ściekach oczyszczonych. Przemysł Chemiczny 5, 432-434.

Cooke, G. D. (1980). Covering bottom sediments as a lake restoration technique. JAWRA Journal of the American Water Resources Association, 16(5), 921-926.

Cooke, G. D., Welch, E. B., Peterson, S. A. (2013). Lake and reservoir restoration. Elsevier.

Cooke, G. D., Welch, E. B., Peterson, S., Nichols, S. A. (2016). Restoration and management of lakes and reservoirs. CRC press.
Czerniawski, R., Sługocki, Ł., Domagała, J., Pilecka-Rapacz, M. (2015). Zabieg krótkoterminowej biomanipulacji ekologicznej zastosowany w trzech śródleśnych płytkich jeziorach. Rocznik Ochrona Środowiska, 17, 1207-1223.

Dunalska, J. A., Wiśniewski, G. (2016). Can we stop the degradation of lakes? Innovative approaches in lake restoration. Ecological Engineering, 95, 714-722.

Gibbs, M. M., Hickey, C. W. (2018). Flocculants and Sediment Capping for Phosphorus Management. In Lake Restoration Handbook, 207-265. Cham: Springer.

Gibbs, M., Özkundakci, D. (2011). Effects of a modified zeolite on $\mathrm{P}$ and $\mathrm{N}$ processes and fluxes across the lake sediment-water interface using core incubations. Hydrobiologia, 661(1), 21-35.

Gibson, G. (2000). Nutrient criteria technical guidance manual: Lakes and reservoirs. US Environmental Protection Agency, Office of Water.

Gulati, R. D., Pires, L. M. D., Van Donk, E. (2008). Lake restoration studies: failures, bottlenecks and prospects of new ecotechnological measures. Limnologica, 38(3-4), 233-247.

Hamilton, D. P., Landman, M. J. (2011). Preface: Lake restoration: an experimental ecosystem approach for eutrophication control. Hydrobiologia, 661(1), 1-3.

Horppila, J., Peltonen, H., Malinen, T., Luokkanen, E., Kairesalo, T. (1998). Top-down or bottom-up effects by fish: issues of concern in biomanipulation of lakes. Restoration ecology, 6(1), 20-28.

Howard-Williams, C., Collier, K. J., Hamilton, D. P., Quinn, J. M. (2018). Reflections on Lake Restoration. In Lake Restoration Handbook, 557-573. Springer, Cham.

http://www.kamiennagora.pl/pl/aktualnosci/zalew-informacja-burmistrza.html

Huang, D. B., Bader, H. P., Scheidegger, R., Schertenleib, R., Gujer, W. (2007). Confronting limitations: New solutions required for urban water management in Kunming City. Journal of Environmental Management, 84(1), 49-61.

Hupfer, M., Reitzel, K., Kleeberg, A., Lewandowski, J. (2016). Long-term efficiency of lake restoration by chemical phosphorus precipitation: scenario analysis with a phosphorus balance model. Water research, 97, 153-161.

Imboden, D. M. (1992). Possibilities and limitations of lake restoration: Conclusions for Lake Lugano. Aquatic Sciences, 54(3-4), 381-390.

Jeppesen, E., Søndergaard, M., Meerhoff, M., Lauridsen, T. L., Jensen, J. P. (2007). Shallow lake restoration by nutrient loading reduction - some recent findings and challenges ahead. In Shallow Lakes in a Changing World. 239-252. Dordrecht: Springer. 
Kaczor, G., Chmielowski, K. Bugajski, P. (2017). Wpływ sumy rocznej opadów atmosferycznych na objętość wód przypadkowych dopływających do kanalizacji sanitarnej, w: Annual Set The Environment Protection, Środkowo-Pomorskie Towarzystwo Naukowe Ochrony Środowiska, 19, 668-681

Kaszycki, P., Krawczyk, A., Kołoczek, H. (2002). Stan i perspektywy biodegradacji ropopochodnych zanieczyszczeń w glebach południowej części Polski. Inżynieria Ekologiczna, 7, 15-22.

Kuriqi, A. (2014). Simulink application on dynamic modeling of biological waste water treatment for aerator tank case. Int. J. Sci. Technol. Res, 3(11), 69-72.

Kuriqi, A., Kuriqi, I., Poci, E. (2016). Simulink programing for dynamic modelling of activated sludge process: aerator and settler tank case. Fresen. Environ. Bull, 25(8), 2891.

Lemmens, P., Declerck, S. A., Tuytens, K., Vanderstukken, M., De Meester, L. (2018). Bottom-up effects on biomass versus top-down effects on identity: A multiple-lake fish community manipulation experiment. Ecosystems, 21(1), 166-177.

Makarewicz, J. C., Bertram, P. (1991). Evidence for the restoration of the Lake Erie ecosystem. Bioscience, 41(4), 216-223.

Mazur, R., Bedla, D., Chmielowski, K., Nowak, A., Mazurkiewicz, J. (2016). Wpływ warunków tlenowych na skuteczność oczyszczania ścieków bytowych w technologii zatapialnych filtrów włókninowych, Przemysł Chemiczny, 96(8), 1513-1517, DOI:10.15199/62.2016.8.18

McDowell, R. W., Monaghan, R. M., Close, M. E., Tanner, C. C. (2018). Agricultural Catchment Restoration. In Lake Restoration Handbook. 107-127. Springer, Cham.

Moss, B. (1990). Engineering and biological approaches to the restoration from eutrophication of shallow lakes in which aquatic plant communities are important components. In Biomanipulation tool for water management. 367-377. Springer, Dordrecht.

Premazzi, G., Cardoso, A.C., Rodari, E., Austoni, M., Chiaudani, G. (2005). Hypolimnetic withdrawal coupled with oxygenation as lake restoration measures: the successful case of Lake Varese (Italy), Limnetica, 24(1-2), 123-132.

Singh, K. P. (1982). Lake Restoration Methods and Feasibility of Water Quality Management in Lake of the Woods. Illinois State Water Survey.

Søndergaard, M., Jeppesen, E. (2007). Anthropogenic impacts on lake and stream ecosystems, and approaches to restoration. Journal of applied ecology, 44(6), 1089-1094 .

Søndergaard, M., Jeppesen, E., Jensen, J. P., Lauridsen, T. (2000). Lake restoration in Denmark. Lakes \& Reservoirs: Research \& Management, 5(3), 151-159.

Søndergaard, M., Jeppesen, E., Lauridsen, T. L., Skov, C., Van Nes, E. H., Roijackers, R., Portielje, R. O. B. (2007). Lake restoration: successes, failures and long-term effects. Journal of Applied ecology, 44(6), 1095-1105.

Søndergaard, M., Liboriussen, L., Pedersen, A. R., Jeppesen, E. (2008). Lake restoration by fish removal: short-and long-term effects in 36 Danish lakes. Ecosystems, 11(8), 1291-1305.

Suding, K. N. (2011). Toward an era of restoration in ecology: successes, failures, and opportunities ahead. Annual review of ecology, evolution, and systematics, 42.

Wąsik, E., Bugajski, P., Chmielowski, K., Nowak, A., Mazur, R. (2017). Crystallization of struvite and hydroxyapatite during removal of biogenic compounds on the filter bed, Przemysł Chemiczny, 96(8), 1739-1743.

Zhang, Y. F., Zhong, W. H., Wang, G. X. (2007). Application of microorganism in bioremediation of contaminated environment [J]. Chinese Journal of Eco-Agriculture, 3.

\section{BIOREMEDIACJA MIKROBIOLOGICZNA ZBIORNIKA ZAPOROWEGO W KAMIENNEJ GÓRZE}

\section{ABSTRAKT}

\section{Cel pracy}

Badanie efektów procesu bioremediacji mikrobiologicznej przeprowadzonej w ramach oczyszczania zbiornika w Kamiennej Górze.

\section{Materiat i metody}

Wykonano szereg pomiarów w terenie, t.j. miąższość osadów dennych, przenikalność światła, oraz analizy fizyko-chemiczne wód. Opisano działania podjęte w procesie bioremediacji. Scharakteryzowano efekty końcowe. 


\section{Wyniki i wnioski}

Proces bioremediacji mikrobiologicznej przyczynił się do redukcji osadów dennych (frakcji organicznych) od 30-100\% w wybranych punktach pomiarowych. Odnotowano poprawę warunków strefy eufotycznej od 70-100\% w badanych punktach. Poziom zanieczyszczeń organicznych w wodzie również uległ częściowej poprawie. Stężenia badanych biogenów nie uległy redukcji, a wręcz w niektórych punktach odnotowano ich wzrost w 2018 r. Pomimo widocznych zmian jakości wody w zbiorniku oraz prawie całkowitej eliminacji frakcji organicznych w osadach dennych można było się spodziewać wzrostu biogenów w wodach zalewu. W ostatnim roku badań odnotowano całkowitą eliminację procesu zakwitu glonów, a w miejscach ich wcześniejszego występowania zlokalizowano ekotony. Zbiornik wciąż narażony jest na presję ze strony zanieczyszczeń wnoszonych przez wody Zadrny. Jeżeli źródła zanieczyszczeń nie zostaną wyeliminowane, tego typu zabiegi będą musiały być powtarzane w kolejnych sezonach w celu utrzymania jakości wód zbiornika.

Słowa kluczowe: bioremediacja jezior eutroficznych, bioremediacja mikrobiologiczna, zanieczyszczenia jezior, degradacja jakości wody 